\title{
O ancylostomo e sua penetração pela via cutanea
}

Por Ernesto de Campos, 5. annista de Medicina.

$\mathrm{E}^{\prime}$ bem sabido que tres são as principaes vias de penetração do ancylóstomo no nosso organismo; entretanto, si as vias buccal e respiratoria são por todos admittidas sem liscrepancia, a via cutanea ñ̃ o é do mesmo modo.

Esta maneira de pensar, creio eu, basea-se na maior parte das vezes, no desconhecimento de bellas e positivas experiencias que têm demonstrado, de um mođto cabal, não só a possibilidade, como, ainda melhor, a realidạde déssa via de penetração; com effeito, não só existe a via cutanea, como ainda ella supera as outras vias na etiologia da ancylóstomiase.

Foram essas considerações que me levaram a escrever este artigo, em que resumo as minhas já resumidas leituras sobre o assumpto ; esta simples declaração deixa de ánte-mão patente que nada de original venho escrever, nada de novo.

O meu intento é o de apagar, do espirito de certos incredulos, essa duvida que não tem ráã̃o de existir, sobretudo em se tratando de uma infecção tão generalisada entre nós e com a qual temos que travar relaçõ s, diariamente.

Foi em 1898 que Looss, n 3 Cairo, manejando liquidos contendo larvas de ancylóstomo, tomava todas as precauções para evitar uma infecção pela bocca, quando, casualmente, algumas gnttas do liquid, cahiram-lhe sobre a pelle do espaço interdigital da mão esqueı da; não dando importancia a esse facto, continuou os seus eistudics; eis senão quando a sua attenção é despertada por uma vermelhidão e prurido localisados no ponto onde havia tomibadio o liquido.

Fazendo uma raspadura do ponto lesado, ainda poude constatar a presença de larvas e cystos vasios.

Aventou, então, a hypothese de que o prurido era causado por' larvas que haviam penetrado na pelle; a confirmação surgiu 3 mezes mais tarde, quando verificou a presença de ovulos de ancylóstomo em suas fézes. 
Orientadio com essa observação que $o$ acaso lhe havia proporcionado, encetou uma serie de experiencias, d'entre as quaes citaremos :

1.a) Tomou um tubo a com agua contendo larvas de ancvlóstomos; deixou, pelo repousu, que éstas se depositassem to fundo do tubo, de sorte que a parte superior do liquido, não as continha mais. Lançando gottas d'esse liquido sobre a pelle, nada se produziu.

Esta experienicia nos mostra que a parte superior das aguas estagnadas é isenta de larvas e d'ahi a pouca probabilidade da infecção, quer pela pelle, quer pela bocca, quando o individuo se põe em conctacto ou bebe aguas estagnadas cujo lodo do fundo não é revolvido.

2.a) Tomou um tubo $b$ em que, de mistura com a agua, existiam numerosas larvas não depositadas; lançando gottas d'esse Iiquido sobre a pelle, logo sentiu pruridos e vermelhidão; deixou evaporar-se a maior parte do liquiddo existente sobre a pelle, soiheu a parte restante e, fazendo n'ella o exame microscopico, constatou a presença de bainhas larvares vasias; as larvas as tinham abandonardo e penetrado na pelle.

3.a) Lançou gottas de um liquido contendo larvas, sobre uma pelle morta; o resultado foi negativo.

4.a) Estando indicada a amputação da perna de um menino de 13 annos, Loss aproveitou-se d'essa opportunidade e, 1 hora antes da operação cirurgica, deitou um pouco de cultura de ancylóstomos sobre a referida perna; 10 minutos depois o liquido se havia evaporado totalmente, sendo que apenas uma vermelhidão indicava onde elle havia sido lançado.

Feita a amputação, a pelle infectada foi excisada e, con o conveniente preparo, examinada ao microscopio; eis o que foi constatado: nos folliculos pilosos encontravam-se larvas em rumeros diversos e em profundidades varias, desde as que começavam a invasão do folliculo, até as que perfurando n seu bulbo, penetravam em pleno derma; ausencia de larvas nas glandulas sebacceas e sudoriparas.

Provado assim, que as larvas penetram pela pelle, faltava provar que eram essas que chegavam ao intestino; ainda foi o proprio Loss quem trabalhou n'esse sentido, fazendo as seguintes experiencias: 
5.a) A 15 de Setembro elle deposita sobre o braço de um enfermeiro, isempto de ancylostomiase, algumas gottas de cultura de ancylóstomos; aos 25 de Novembro, já o exame revelava a presença de bvulos nas fezes.

6.a) Applicando culturas de ancylostomo caninum, na pelle de um cão, verificou a morte do animal, ao fim de 10 dias, com innumeras larvas no intestino e nenhuma na pelle.

Em 1904, Goldmann, na Austria, começou a observar certas erupções da pelle, semelhantes á urticaria, em mineiros que se punham em contacto com o lodo do fundo das minas: nove semanas depois d'essas erupções, o exame das fezes denotava a presença de ovulos de ancylóstomos; o mesmo facto se dava com macacos, cuja pelle era friccionada com fezes contendo larvas.

Em 1905, Calmette e Breton, na França, confirmam, perante a Academia de Medicina, os trabalhos de Loss, que ainda foram ratificados por Sandwith, Schaudinn, Hermann, Schuffner, Smith, etc. Entre nós, si me não engano, o Institúto de Manguinhos collocou-se, experimentando, ao lado dos que approvam esse modo de vêr.

Qual o trajecto seguido pela larva, para ir da pelle ao intestino?

Para Loss; segundo a sua communicação feita ao Congresso internacional de zoologia de Berńa, em 1904, as larvas do ancylóstomo penetram nos vasos venenosos ou lymphaticos da pelle, são levadas a) coração direito; lançadas na pequena circulação, surgem nos alveolos pulmonares, d'onde são expellidas em conjuncto com mucọsidades, que vão ao nesophago, estomago, intestino.

Esta ultima parte, porém, nãc faz parte do nosso escopo que é o de provar a realidade da penetração dás larvas de ancylóstomo pela via cutanea.

Como supplemento a esta simples recapitulação, (pois que, como já deixei patente, não estou escrevendo novidades) devo lembrar que, em penetrando pela pelle, as larvas de ancylóstomo ahi provocam uma dermatose, uma ancylostomiase cutanea (conhecida por uma infinidade de denominações) que, talvez pela sua benignidade, é pouco pesquiśada nos doentes que pullulam pelas nossas enfermarias; creio, entretanto, 
que essa pesquisa deveria ser feita com algum interesse, porque nenhum conhecimento deverá ser considerado como superfluo, em uma molestia tão espalhada entre nós e que tantos prejuizos nos causa.

\title{
Toxicodernias consecutivas ao tratamento da syphilis
}

\author{
Pelo quarto innista Romeu da Silveire
}

Todos os medicamentos actualmente utilisados no trata. mento da syphilis, provêm, em sua quasi que totalidade, de tres corpos ehimicos, os quaes, como muito bem se sabe, sã o iodo, o mercurio e o arsenico. E' sobre a acção toxica que qualquer um delles possa exercer sobre a pelle, que pretendemos fazer este ligeiro e despretencioso estudo o qual, affirmamos desde já, será por certo bastante incompleto. Esta questão de toxicodermias tem sido despresada por quasi todos e muitas vezes, para não dizer quasi sempre, pensa-se que certas erupções toxicas da pelle, em individuos submettidos á therapeutica anti-luetica, sejam apenas lesões syphiliticas; e é bem triste constatar-se, como já tivemos occasião, o facto de terem sido receitadas as pilulas de Ricord a um individuo que apresentava $A C N E$ IODICA typica na fronte, como si tal exanthema fôra syphilitico.

\section{$I O D O$}

O iodo, descoberto em 1811 por BERNARDO COURTOIS, foi por WALLACE de Dublin, preconisado pela primeira vez no tratamento da syphilis, sob a fórma de iodeto de potassio, tratamento esse que, graças ao grande RICORD, foi largamente vulgarisado em França sobretudo contra a syphilis terciaria, da qual é elle hoje o especifico. Porém, sobre ser medicamento anti-luetico, póde, o metalloide de COURTOIS, actuar tambem sobre o organismo, produzindo não raramente graves envenenamentos. 